Pengaruh Lama Pemanasan dan Konsentrasi Maizena - Gunawan, dkk Jurnal Pangan dan Agroindustri Vol.6 No.1:1-11, Januari 2018

\title{
PENGARUH LAMA PEMANASAN DAN KONSENTRASI MAIZENA TERHADAP KARAKTERISTIK FISIK, KIMA, DAN ORGANOLEPTIK LEMPOK JAMBU BIJI MERAH (Psidium guajava L.)
}

\section{The Effect of Heating Time and Maize Concentration on Physical, Chemical, and Organoleptic Characteristic of Red Guava (Psidium guajava L.) Lempok}

\author{
Rudi Gunawan*, Wahono Hadi Susanto, Novita Wijayanti \\ Jurusan Teknologi Hasil Pertanian, FTP Universitas Brawijaya Malang \\ JI. Veteran, Malang 65145 \\ *Penulis Korespondensi, email: rudigunawan_19@yahoo.co.id
}

\begin{abstract}
ABSTRAK
Jambu biji merah memiliki produktivitas cukup tinggi dan dapat tersedia sepanjang tahun. Produksi jambu biji di Indonesia pada tahun 2014 mencapai 187.406 ton. Namun, jambu biji memiliki umur simpan yang pendek sehingga perlu dilakukan pengolahan. Lempok merupakan makanan semi basah yang memiliki tekstur yang liat. Lama pemanasan dan konsentrasi maizena dapat berpengaruh terhadap kualitas lempok yang dihasilkan. Metode yang digunakan Rancangan Acak Kelompok dengan 2 faktor. Faktor I adalah lama pemanasan yang terdiri dari 3 level ( 1 jam; 1,5 jam; dan 2 jam). Faktor II adalah konsentrasi maizena yang terdiri atas 3 level (5\%; 7.50\%; dan 10\%). Tingkat lama pemanasan berpengaruh sangat nyata terhadap kadar air, asam askorbat, total gula, serat kasar, tekstur, kecerahan, kekuningan, kemerahan, dan organoleptik. Perlakuan tingkat konsentrasi maizena berpengaruh sangat nyata terhadap kadar air, tekstur, kemerahan, kekuningan, dan organoleptik, sedangkan parameter total gula dan kecerahan berpengaruh nyata. Lempok jambu biji merah terbaik adalah lempok dengan perlakuan lama pemanasan 2 jam dan konsentrasi maizena $7.50 \%$.
\end{abstract}

Kata kunci: Jambu Biji Merah, Lama Pemanasan, Lempok, Maizena

\section{ABSTRACT}

Red guava has high productivity and available throughout the year. Guava production in Indonesia at 2014 is 187.406 tons. However, red guava has a weakness at the short selflife, so there is necessary to processing. Lempok is a semi-solid food has a clay texture. The heating time and maize concentration affected to the quality of lempok. This research uses Randomized Block Design method with 2 factors. First factor is cooking time which consists of 3 levels (1 hour, 1.5 hours, and 2 hours). And the second factor is maize concentration consist of 3 levels (5\%, 7.50\%, and 10\%). Heating time level had a significant effect on water content, ascorbate acid, total sugar, crude fiber content, texture, brightness, yellowness, redness, and organoleptic. Level of maize concentration had a significant effect on water content, texture, redness, yellowness, and organoleptic, while total sugar and brightness have effect. The best red guava lempok were found at lempok with heating time 2 hours and $7.50 \%$ maize concentration.

Keywords: Heating Time, Lempok, Maize, Red Guava

\section{PENDAHULUAN}

Jambu biji merah memiliki produktivitas cukup tinggi dan dapat tersedia sepanjang tahun. Menurut Data Kementerian Pertanian (2015), produksi jambu biji di Indonesia pada tahun 2014 mencapai 187.406. Jawa Timur merupakan salah satu sentra produksi jambu biji merah 
dengan produksi mencapai 26.590 ton pada tahun 2014. Jambu biji merah juga memiliki kandungan vitamin C cukup tinggi yaitu $87 \mathrm{mg}$ dalam 100 gram (Direktorat Gizi Depkes RI, 1996). Produktivitas yang tinggi dan keunggulan nilai gizi dari jambu biji merah tidak diimbangi dengan umur simpannya yang sangat pendek. Apabila tidak dimanfaatkan dengan baik maka akan menyebabkan kerugian, sehingga perlu dilakukan pengolahan. Salah satu produk olahan yang bisa dihasilkan dari jambu biji merah adalah lempok.

Lempok merupakan jenis makanan yang memiliki tekstur liat dikarenakan adanya pembentukan gel oleh asam, pektin, dan gula. Selain pektin, pembentukan gel juga dipengaruhi penambahan pengental. Pada lempok durian, umumnya menggunakan tepung ketan sebagai pengental, namun pada lempok jambu biji merah pengental yang dipakai yaitu maizena karena jenis pati ini tidak mempengaruhi flavour dari lempok. Penambahan maizena bertujuan untuk membantu pembentukan gel pada lempok jambu biji merah. Karena maizena merupakan salah satu jenis pati yang memiliki sifat fungsional yang berkaitan dengan daya serap air, viskositas gel, kerekatan, dan tekstur. Kombinasi lama pemanasan dan penambahan konsentrasi maizena mungkin akan saling sinergis dalam proses pembentukan gel.

Lama pemanasan dan penambahan konsentrasi maizena yang tepat akan menghasilkan lempok berkualitas baik dengan tekstur liat dan waktu produksi yang efisien. Pengolahan jambu biji merah menjadi lempok akan meningkatkan nilai tambah dari jambu biji merah. Lempok jambu biji merah dapat menjadi inovasi olahan pangan tradisional, dengan adanya inovasi tersebut masyarakat dapat menikmati olahan jambu biji merah yang lebih bervariasi.

\section{BAHAN DAN METODE}

\section{Bahan}

Bahan yang digunakan dalam pembuatan lempok jambu biji merah adalah jambu biji merah matang yang diperoleh dari perkebunan jambu biji di Kota Batu. Bahan lain yang digunakan yaitu gula, maizena, dan margarin, yang akan di dapatkan di toko kue Prima Rasa di Malang.

Bahan yang digunakan untuk analisa adalah asam oksalat, indikator $\mathrm{PP}, \mathrm{NaOH} 0,1 \mathrm{~N}$, etanol 95\%, larutan $\mathrm{K}_{2} \mathrm{SO}_{4} 10 \%$, larutan $\mathrm{H}_{2} \mathrm{SO}_{4} 0,255 \mathrm{~N}$, Iarutan $\mathrm{NaOH} 0,313 \mathrm{~N} \mathrm{HCl} 36 \mathrm{~N}$, pereaksi Anthrone 0,1\%, larutan glukosa standar, $\mathrm{CaCO}_{3}, \mathrm{H}_{2} \mathrm{SO}_{4}$ pekat $97 \%$, $\mathrm{Na}$ Oksalat, $\mathrm{Pb}$ Asestat, $\mathrm{KI}, \mathrm{I}_{2}$, asam askorbat, larutan amilum $1 \%$, larutan yodium $0,01 \mathrm{~N}$, dan aquades.

\section{Alat}

Alat yang digunakan dalam pembuatan lempok jambu biji merah adalah baskom, pisau, sendok, blender, timbangan (merk scaleman S-95), termometer, panci, pengaduk kayu, talenan, dan kompor gas (merk Rinnai). Alat yang digunakan dalam analisa adalah neraca analitik (merk Denver M 310 USA), oven listrik (WTB Binder), desikator (merk Scoot Duran), lemari asam, spektrofotometer beserta kuvet (UNICO RRC UV 2100), vortex-mixer (Model VM 2000), kertas saring halus, kompor listrik (merk Maspion), pompa vakum, pendingin balik, bola hisap, buret, statip, dan glass ware merk Pyrex.

\section{Desain Penelitian}

Rancangan percobaan yang digunakan adalah Rancangan Acak Kelompok dengan 2 faktor. Faktor I adalah lama pemanasan yang terdiri dari 3 level (1; 1.5; dan 2 jam). Faktor II adalah konsentrasi maizena yang terdiri atas 3 level (5; 7.50; dan 10\%).

\section{Tahapan Penelitian}

Jambu biji merah dicuci hingga bersih lalu dikupas kulitnya. Jambu kemudian dibelah menjadi empat bagian dan dibuang bijinya. Dilakukan steam blanching terhadap jamu biji merah selama 5 menit, lalu didinginkan. Setelah itu dihancurkan selama 15 detik dengan menggunakan blendersampai menjadi slurry. Slurrykemudian ditimbang sebanyak $600 \mathrm{~g}$ dan ditambah maizena $5 \%, 7.50 \%$ dan $10 \%$, gula $7.50 \%$, dan margarin $2.50 \%$. Dilakukan 
pemasakan dan pengadukan suhu $80 \pm 2^{\circ} \mathrm{C}$ selama waktu $1 ; 1.5$; dan 2 jam. Setelah matang lempok jambu biji mwerah dilakukan pengemasan.

\section{Prosedur Analisis}

Analisis meliputi kadar air (Sudarmadji dkk, 1996), asam askorbat (Sudarmadji dkk, 1996), total gula metode Anthrone (AOAC, 1990), serat kasar (AOAC, 1995), kadar pektin (AOAC, 1995), total asam (Apriyanto, 1989), tekstur (tensile strength), warna (colour reader), uji organoleptik (Rahayu, 2001) dan uji perlakuan terbaik (Zeleny, 1982). Analisa data dilakukan dengan menggunakan metode Analysis of Variance (ANOVA) untuk mengetahui pengaruh pada setiap perlakuan. Apabila hasil uji menunjukkan beda nyata dan terjadi interaksi, maka dilakukan uji DMRT (Duncan's Multiple Range Test). Namun apabila hasil uji hanya berbeda nyata tapi tidak terjadi interaksi maka dilakukan uji BNT (Beda Nyata Terkecil).

\section{HASIL DAN PEMBAHASAN}

\section{Bahan Baku}

Bahan yang digunakan dalam pembuatan lempok jambu biji merah adalah jambu biji merah matang. Jambu biji merah yang sudah matang secara fisik memiliki warna kekuningan, tekstur yang cukup lunak, aroma jambu biji yang khas, dan bagian dalam yang berwarna merah. Data hasil analisis masing masing bahan baku apel dibandingkan pustaka ditunjukkan pada Tabel 1.

Tabel 1. Perbandingan Hasil Analisis Bahan Baku Buah Jambu Biji Merah dengan Literatur

\begin{tabular}{|c|c|c|}
\hline \multirow{2}{*}{ Parameter } & \multicolumn{2}{|c|}{ Buah Jambu Biji Merah Matang } \\
\hline & Hasil Analisis & Literatur \\
\hline Air (\%bb) & 87.52 & $86.00^{\mathrm{a}}$ \\
\hline Total Gula (\%bb) & 11.92 & $12.20^{\mathrm{a}}$ \\
\hline Total Asam (\%) & 0.37 & $0.30^{\mathrm{b}}$ \\
\hline Asam Askorbat (mg/100g) & 80.38 & $87.00^{\mathrm{a}}$ \\
\hline Pektin (\%) & 0.66 & $0.50-1.80^{b}$ \\
\hline Warna: & & \\
\hline Kecerahan $\left(L^{*}\right)$ & 71.78 & - \\
\hline Kemerahan (a) & 40.90 & - \\
\hline Kekuningan (b) & 8.80 & - \\
\hline Tekstur & 6.10 & \\
\hline
\end{tabular}

Keterangan: a: Direktorat Gizi Depkes RI (1996),

b: Salunkhe dan Desai (1984)

Perbedaan kandungan gizi jambu biji merah hasil analisis dengan literatur diduga dikarenakan beberapa faktor yaitu perbedaan jenis jambu biji, perbedaan umur panen, perbedaan proses penanganan pasca panen, dan perbedaan geografis tempat tanaman tumbuh.

\section{Kadar Air Lempok Jambu Biji Merah}

Kadar air lempok jambu biji merah berkisar antara 11.48 - 31.89\%. Pengaruh perlakuan lama pemanasan dan konsentrasi maizena terhadap kadar air lempok jambu biji merah dapat dilihat pada Gambar 1. 


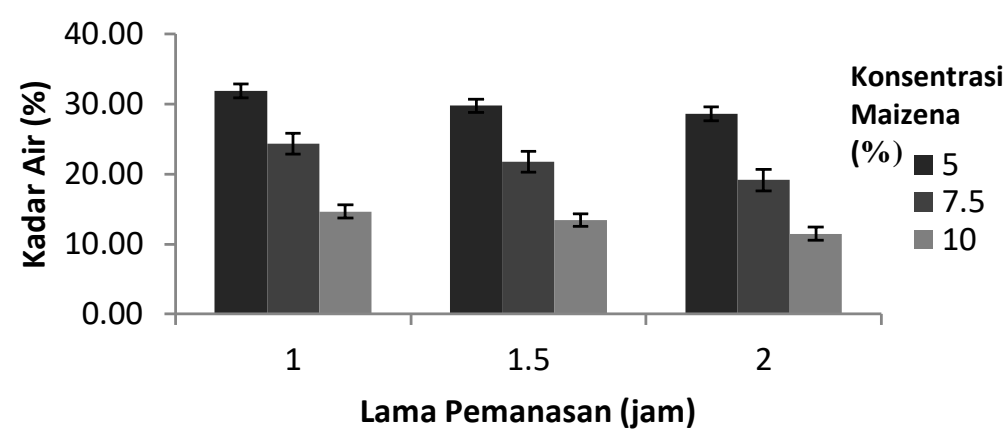

Gambar 1. Pengaruh Lama Pemanasan (jam) dan Konsentrasi Maizena (\%) terhadap Kadar Air Lempok Jambu Biji Merah.

Kadar air lempok jambu biji merah semakin menurun seiring dengan semakin lama pemanasan dan penambahan konsentrasi maizena yang semakin banyak pada saat proses pembuatan lempok jambu biji merah. Kadar air terendah diperoleh dari perlakuan lama pemanasan 2 jam dengan konsentrasi maizena 10\%, sedangkan kadar air tertinggi diperoleh dari perlakuan lama pemanasan 1 jam dengan kkonsentrasi maizena $5 \%$. Penurunan kadar air pada lempok jambu biji merah dikarenakan adanya penguapan air karena proses pemanasan. Semakin lama pemanasan maka akan semakin banyak air yang menguap dari bahan sehingga kadar air pada bahan semakin turun. Menurut Taib dkk (1988) dalam Histifarina dkk (2004), menyatakan bahwa kemampuan bahan untuk melepaskan air dari permukaannya akan semakin besar dengan meningkatnya suhu dan semakin lamanya proses pemanasan, sehingga kadar air yang dihasilkan semakin rendah. Konsentrasi maizena berpengaruh terhadap kadar air pada lempok jambu biji merah. Semakin tinggi konsentrasi maizena maka kadar air pada lempok jambu bij merah akan semakin turun. Banyaknya konsentrasi maizena menyebabkan total padatan dalam lempok semakin meningkat sehingga kadar airnya semakin menurun.

\section{Kadar Asam Askorbat Lempok Jambu Biji Merah}

Rerata asam askorbat lempok jambu biji merah berkisar antara $36.42-50.73 \%$. Pengaruh perlakuan lama pemanasan dan konsentrasi maizena terhadap asam askorbat dapat dilihat pada Gambar 2.

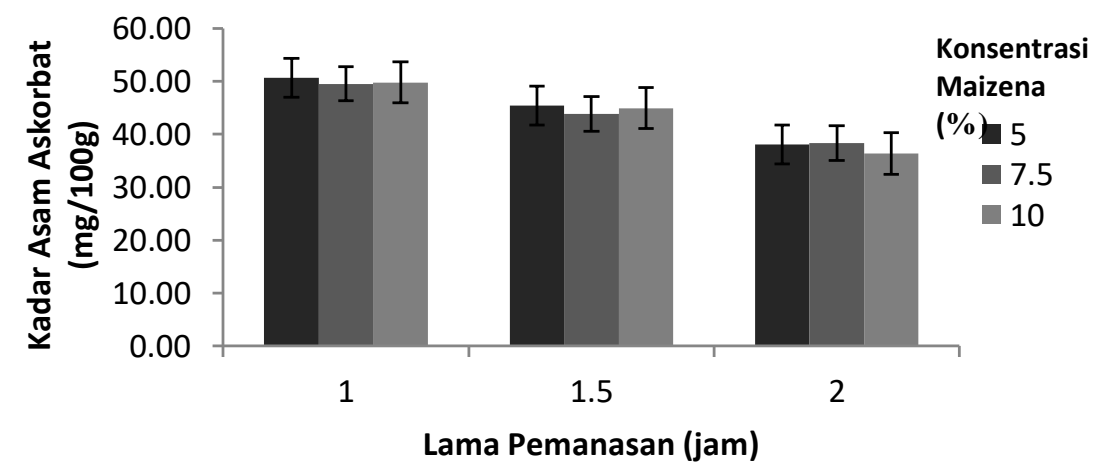

Gambar 2. Pengaruh Lama Pemanasan (jam) dan Konsentrasi Maizena (\%) terhadap Kadar Asam Askorbat Lempok Jambu Biji Merah.

Semakin lama waktu pemanasan maka kadar asam askorbat yang ada pada lempok jambu biji merah akan semakin menurun. Berbeda dengan perlakuan konsentrasi maizena, kadar asam askorbat pada lempok jambu biji merah fluktuatif. Kadar asam askorbat tertinggi ada pada lempok dengan perlakuan lama pemasan 1 jam dengan konsentrasi maizena $5 \%$. Kadar asam askorbat yang tertinggi yaitu sebesar $50.73 \mathrm{mg} / 100 \mathrm{~g}$. Perlakuan lama 
pemanasan 2 jam dengan konsentrasi maizena 10\% menghasilkan lempok dengan kadar asam askorbat terendah yaitu sebesar $36.42 \mathrm{mg} / 100 \mathrm{~g}$. semakin menurunnya kadar asam askorbat dikarenakan bahan mengalami kontak dengan panas yang semakin lama. Menurut Winarno (2002), kerusakan asam askorbat bisa diakibatkan karena panas, sinar, enzim, oksidasi, alkali, dan ion logam. Proses pembuatan lempok jambu biji merah yang mengguakan suhu tinggi dapat menyebabkan kerusakan terhadap asam askorbat.

\section{Total Gula Lempok Jambu Biji Merah}

Rerata total gula lempok jambu biji merah berkisar antara $29.84-55.64 \%$. Pengaruh perlakuan lama pemanasan dan konsentrasi maizena terhadap total gula dapat dilihat pada Gambar 3.

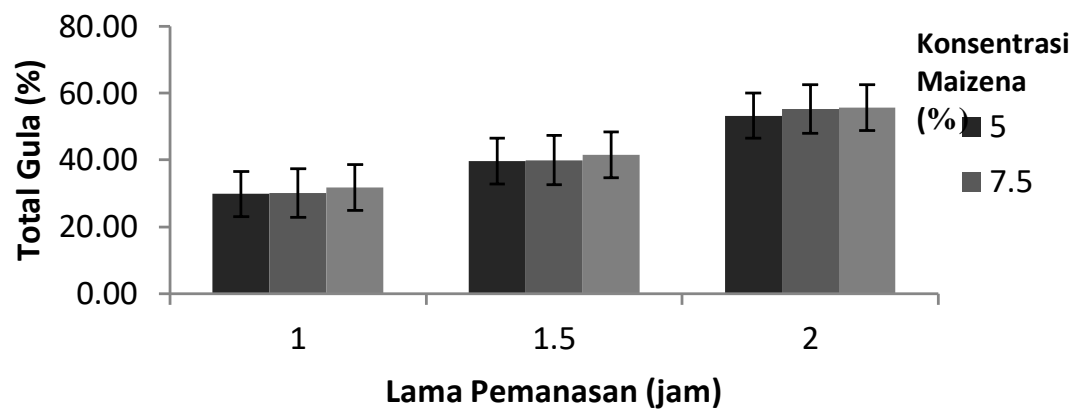

Gambar 3. Pengaruh Lama Pemanasan (jam) dan Konsentrasi Maizena (\%) terhadap Total Gula Lempok Jambu Biji Merah

Semakin lama pemanasan maka semakin tinggi total gula dan semakin tinggi penambahan konsentrasi maizena maka total gula semakin menurun. Perlakuan lama pemanasan 2 jam dan penambahan konsentrasi maizena $10 \%$ menghasilkan total gula tertinggi yaitu sebesar $55.64 \%$. Perlakuan lama pemanasan 1 jam dan penambahan konsentrasi maizena $5 \%$ menghasilkan total gula tertinggi yaitu sebesar $29.84 \%$. Semakin lamanya waktu pemanasan maka total gula dari lempok jambu biji merah akan semakin meningkat. Total gula pada lempok jambu biji merah dipengaruhi oleh bahan lain yang terkandung dalam lempok, diantaranya yaitu kadar air. Semakin rendah kadar air pada lempok maka presentase kandungan total gula akan semakin tinggi. Kadar air akan semakin rendah apabila lempok dimasak dengan waktu yang lebih lama. Menurut Taib dkk (1988) dalam Histifarina dkk (2004), menyatakan bahwa kemampuan bahan untuk melepaskan air dari permukaannya akan semakin besar dengan meningkatnya suhu dan semakin lamanya proses pemanasan, sehingga kadar air yang dihasilkan semakin rendah. Grafik hubungan antara kadar air dan total gula pada lempok jambu biji merah dapat dilihat pada Gambar 4.

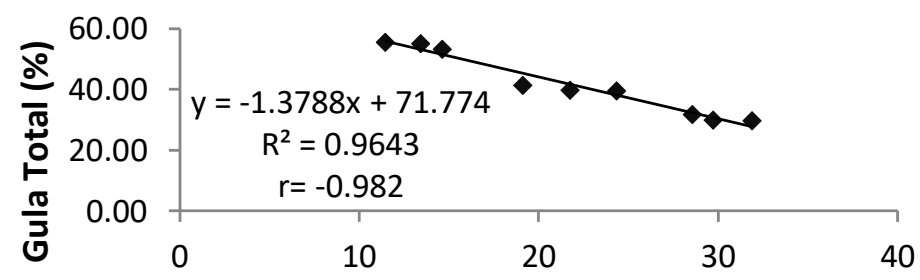

Kadar Air (\%)

Gambar 4. Grafik Korelasi Kadar Air dan Total Gula Lempok Jambu Biji Merah

Nilai koefisien yang diperoleh dari grafik korelasi antara kadar air dan gula yaitu 1.3788 yang menunjukkan bahwa setiap penurunan 1\% kadar air akan menaikkan $1.3788 \%$ kadar total gula. Nilai r menunjukkan korelasi yang merupakan hubungan keeratan antar kadar air dengan total gula. Dari grafik tersebut diperoleh nilai $r$ sebesar -0.982 . Nilai korelasi berkisar antara -1 hingga 1 . Korelasi negatif menandakan bahwa semakin tinggi kadar air 
maka total gula semakin rendah. Nilai korelasi yang semakin mendekati -1 menunjukan bahwa korelasi negatif yang semakin kuat.

\section{Serat Kasar Lempok Jambu Biji Merah}

Rerata total gula lempok jambu biji merah berkisar antara $29.84-55.64 \%$. Pengaruh perlakuan lama pemanasan dan konsentrasi maizena terhadap kadar serat kasar dapat dilihat pada Gambar 5.

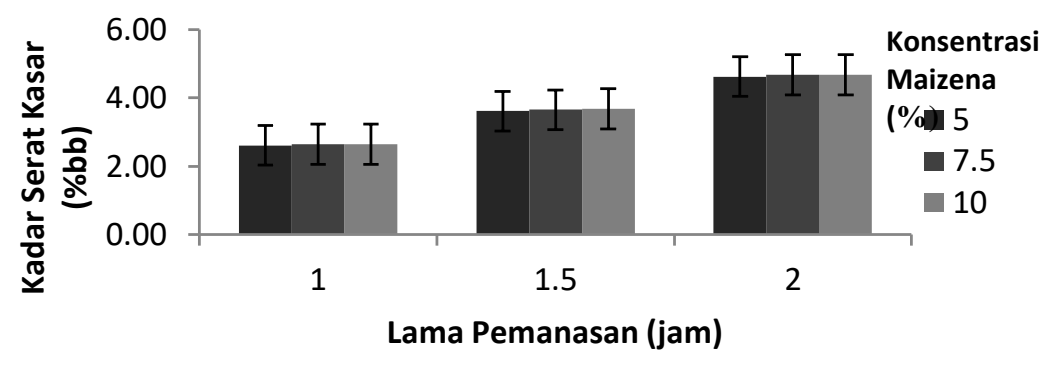

Gambar 5. Pengaruh Lama Pemanasan (jam) dan Konsentrasi Maizena (\%) terhadap Serat Kasar Lempok Jambu Biji Merah

Semakin lama waktu pemanasan dan semakin banyak konsentrasi maizena yang ditambahkan akan membuat kadar serat kasar semakin tinggi. Perlakuan lama pemanasan 2 jam dengan konsentrasi maizena $10 \%$ menghasilkan kadar serat kasar tertinggi yaitu $4.68 \%$, sedangkan hasil terendah yaitu $2.61 \%$ diperoleh dari perlakuan lama pemanasan 1 jam dengan konsentrasi maizena $5 \%$. Semakin lama pemanasan saat proses pembuatan lempok maka kandungan serat kasar akan semakin meningkat. Semakin lama waktu pemanasan yang digunakan pada proses embuatan lempok kandungan air yang teruapkan semakin banyak (Desrosier, 2007). Kandungan air yang menguap semakin banyak menyebabkan total padatan pada bahan pangan akan semakin meningkat, salah satunya yaitu serat kasar. Kadar serat akibat perlakuan konsentrasi maizena menunjukkan bahwa semakin tinggi konsentrasi maizena yang diberikan maka kadar serat pada lempok jambu biji merah akan semakin meningkat. Maizena merupakan pati yang terbuat dari bahan jagung. Biji jagung sendiri memiliki kandungan serat kasar sebanyak 2.10-2.30\% (Lopulalan, 2008), yang dapat menyebabkan terjadinya peningkatan kandungan serat kasar pada lempok jambu biji merah. Grafik hubungan antara kadar air dan serat kasar pada lempok jambu biji merah dapat dilihat pada Gambar 6

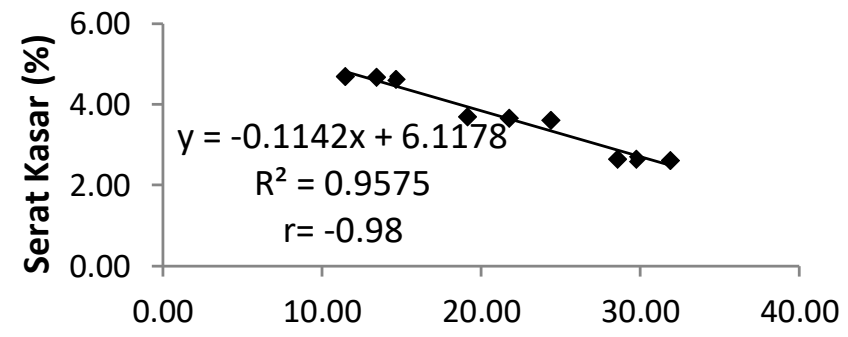

Kadar Air (\%)

Gambar 6. Grafik Korelasi Kadar Air dan Serat Kasar Lempok Jambu Biji Merah

Nilai koefisien yang diperoleh dari grafik korelasi antara kadar air dan serat kasar yaitu -0.1142 yang menunjukkan bahwa setiap penurunan $1 \%$ kadar air akan menaikkan $0.1142 \%$ kadar serat kasar. Nilai $r$ menunjukkan korelasi yang merupakan hubungan keeratan antar kadar air dengan serat kasar. Dari grafik tersebut diperoleh nilai r sebesar -0.98 . Nilai korelasi berkisar antara -1 hingga 1 . Korelasi negatif menandakan bahwa semakin tinggi kadar air maka serat kasar semakin rendah. Nilai korelasi yang semakin mendekati -1 menunjukkan bahwa korelasi negatif yang semakin kuat. 


\section{Tekstur (Tensile Strength) Lempok Jambu Biji Merah}

Rerata nilai tekstur lempok jambu biji merah berkisar antara $2.90-11.67 \mathrm{~N}$. Pengaruh perlakuan lama pemanasan dan konsentrasi maizena terhadap tekstur dapat dilihat pada Gambar 7.

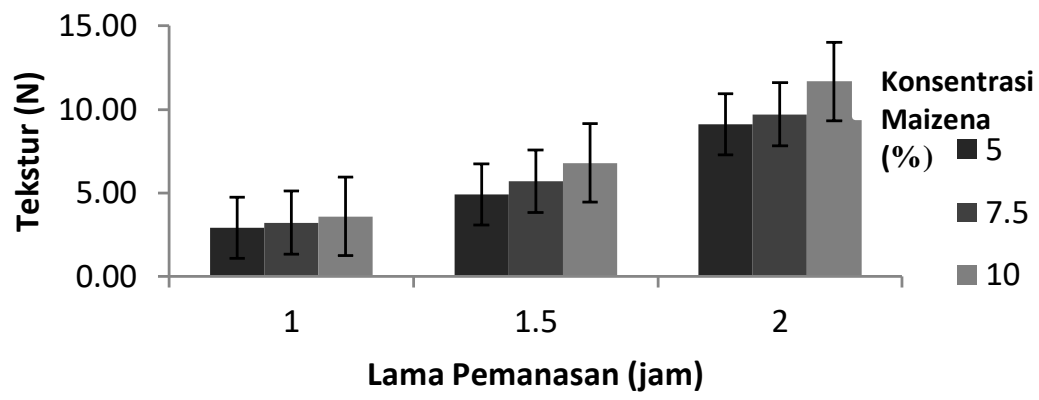

Gambar 7. Pengaruh Lama Pemanasan (jam) dan Konsentrasi Maizena (\%) terhadap Tekstur (N) Lempok Jambu Biji Merah

Semakin tinggi lama pemanasan dan semakin konsensentrasi maizena maka nilai tekstur akan semakin tinggi atau tekstur pada lempok jambu biji merah semakin keras. Perlakuan lama pemanasan 1 jam dan konsentrasi maizena $5 \%$ menghasilkan lempok bertekstur paling lunak dengan nilai tekstur sebesar 2,90 N, sedangkan pada perlakuan lama pemanasan 2 jam dan konsentrasi maizena 10\% menghasilkan lempok bertekstur paling keras dengan nilai tekstur sebesar $11.67 \mathrm{~N}$. Semakin lama waktu pemanasan yang diberikan saat proses pembuatan lempok jambu biji merah maka nilai tekstur akan semakin tinggi atau tekstur lempok jambu biji merah semakin keras. Peningkatan nilai tekstur disebabkan karena meningkatnya total padatan pada suatu bahan. Peningkatan total padatan merupakan hasil dari peningkatan presentase seluruh komponen adonan (Priscilla, 2013). Semakin lama waktu pemanasan dapat menyebabkan kandungan air yang teruapkan dari bahan akan semakin banyak sehingga total padatan akan semakin tinggi sehingga mengakibatkan tekstur lempok jambu biji merah semakin keras. Grafik hubungan antara kadar air dan serat kasar pada lempok jambu biji merah dapat dilihat pada Gambar 8.

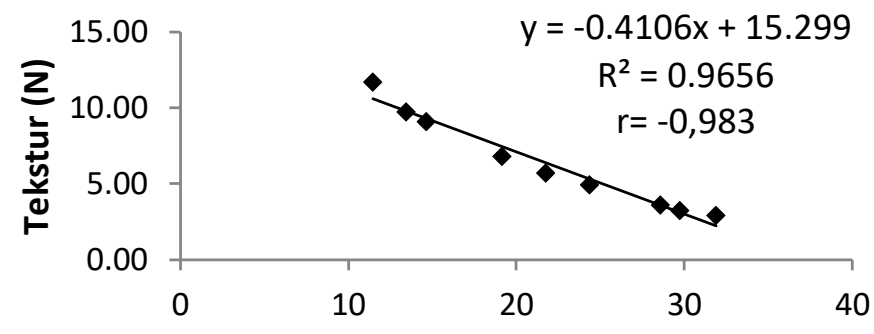

\section{Kadar Air (\%)}

Gambar 8. Grafik Korelasi Kadar Air dan Tekstur Lempok Jambu Biji Merah

Nilai koefisien yang diperoleh dari grafik korelasi antara kadar air dan serat kasar yaitu -0.4106 yang menunjukkan bahwa setiap penurunan $1 \%$ kadar air akan menaikkan $0.4106 \%$ nilai tekstur. Nilai $r$ menunjukkan korelasi yang merupakan hubungan keeratan antar kadar air dengan tekstur. Dari grafik tersebut diperoleh nilai $r$ sebesar -0.983 . Nilai korelasi berkisar antara -1 hingga 1 . Korelasi negatif menandakan bahwa semakin tinggi kadar air maka nilai tekstur semakin rendah atau semakin lunak. Nilai korelasi yang semakin mendekati -1 menunjukan bahwa korelasi negatif yang semakin kuat. Purnomo (1995), menyatakan bahwa aktivitas air dan kadar air bahan pangan berperan utama pada sifat tekstur bahan pangan tersebut. Produk yang memiliki kadar air tinggi cenderung memiliki tekstur produk yang basah, empuk dan mudah dikunyah, sebaliknya kondisi bahan pangan yang kering sekali, sangat keras dan tidak mudah dikunyah. 


\section{Warna (Color Reader) Lempok Jambu Biji Merah}

a. Tingkat Kecerahan $\left(L^{*}\right)$

Rerata nilai tingkat kecerahan lempok jambu biji merah berkisar antara $40.07-44.10$. Pengaruh perlakuan lama pemanasan dan konsentrasi maizena terhadap tekstur dapat dilihat pada Gambar 9.

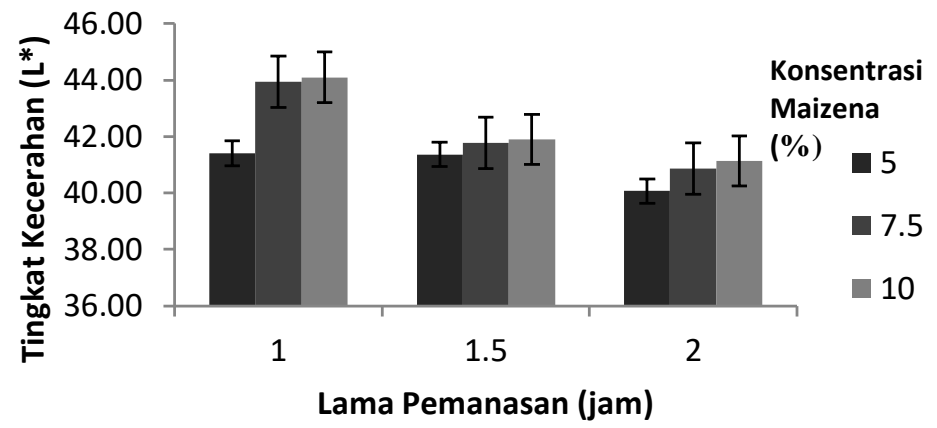

Gambar 9. Pengaruh Lama Pemanasan (jam) dan Konsentrasi Maizena (\%) terhadap Tingkat Kecerahan Lempok Jambu Biji Merah

Semakin lama waktu pemanasan yang diberikan pada proses pembuatan lempok jambu biji merah maka tingkat kecerahannya $\left(L^{*}\right)$ semakin rendah, sedangkan semakin banyak konsentrasi maizena yang ditambahkan maka tingkat kecerahan $\left(L^{*}\right)$ semakin tinggi. Perlakuan lama pemanasan 1 jam dengan konsentrasi maizena 10\% menghasilkan tingkat kecerahan $\left(L^{*}\right)$ tertinggi yaitu sebesar 44.10 , sedangkan perlakuan lama pemanasan 2 jam dengan konsentrasi maizena 5\% menghasilkan tingkat kecerahan $\left(L^{*}\right)$ terendah yaitu sebesar 40.07. semakin lama waktu pemanasan saat proses pembuatan lempok jambu biji merah maka kecerahan lempok jambu biji merah akan semakin menurun. Semakin menurunnya nilai $L$ yang berarti semakin gelapnya warna dari lempok jambu biji merah bisa disebabkan karena reaksi pencoklatan. Reaksi pencoklatan yang mungkin terjadi pada lempok jambu biji merah adalah reaksi maillard yang merupakan pencoklatan non enzimatis. Reaksi ini terjadi akibat adanya gugus karbonil dari karbohidrat (gula reduksi) dan asam amino dari protein yang terjadi pada suhu tinggi (Darwindra, 2009).

Reaksi pencoklatan lain yang menyebabkan lempok jambu biji merah semakin gelap yaitu pencoklatan akibat vitamin $\mathrm{C}$ mengingat kandungan vitamin $\mathrm{C}$ yang ada dalam jambu biji merah cukup tinggi. Pencoklatan akibat vitamin $\mathrm{C}$ merupakan pencoklatan non enzimatis. Vitamin C (asam askorbat) merupakan suatu senyawa reduktor dan juga dapat bertindak sebagai prekursor untuk pembentukan warna cokelat nonenzimatik. Asam-asam askorbat berada dalam keseimbangan dengan asam dehidrokaskorbat. Dalam suasana asam, cincin lakton asam dehidroaskorbat terurai secara irreversible dengan membentuk suatu senyawa diketogulonati kemudian berlangsung proses pencoklatan (Winarno, 1989).

\section{b. Tingkat Kemerahan ( $\left.a^{\star}\right)$}

Rerata nilai tingkat kemerahan lempok jambu biji merah berkisar antara $22.70-33.10$. Pengaruh perlakuan lama pemanasan dan konsentrasi maizena terhadap tekstur dapat dilihat pada Gambar 10. 


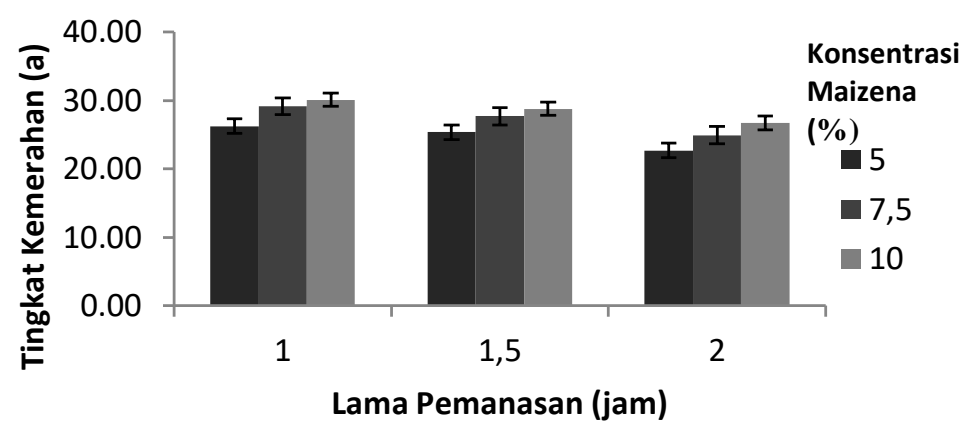

Gambar 10. Pengaruh Lama Pemanasan (jam) dan Konsentrasi Maizena (\%) terhadap Tingkat Kemerahan Lempok Jambu Biji Merah

Semakin lama waktu pemanasan pada saat proses pembuatan lempok jambu biji merah maka tingkat kemerahan (a) akan semakin rendah, sedangkan semakin banyak konsentrasi maizena yang ditambahkan maka tingkat kemerahan (a) akan semakin tinggi. Tingkat kemerahan lempok jambu biji merah terendah diperoleh dari perlakuan lama pemanasan 2 jam dengan konsentrasi maizena $5 \%$ yaitu sebesar 22.70 , sedangkan tingkat kemerahan tertinggi diperoleh dari perlakuan lama pemanasan 1 jam dengan konsentrasi maizena $10 \%$ yaitu sebesar 30.10 . Semakin lama waktu pemanasan yang diberikan saat proses pembuatan lempok jambu biji merah maka tingkat kemerahan akan semakin rendah. Lempok jambu biji merah mempunyai warna merah dari bahan baku jambu biji merah. Jambu biji merah memiliki kandungan pigmen likopen yang memberikan warna merah pada buah jambu biji merah (Parimin, 2005). Likopen pada prinsipnya merupakan pigmen yang berwarna merah kekuningan. Proses pemanasan yang diberikan pada saat proses pembuatan lempok jambu merah mengakibatkan penurunan stabilitas warna. Menurut Winarti (2008), proses pemanasan sampai suhu $80^{\circ} \mathrm{C}$ akan menyebabkan penurunan stabilitas warna pigmen yang ada pada bahan.

\section{c. Tingkat Kekuningan (b*)}

Rerata nilai tingkat kekuningan lempok jambu biji merah berkisar antara $11.93-23.50$. Pengaruh perlakuan lama pemanasan dan konsentrasi maizena terhadap tekstur dapat dilihat pada Gambar 11.

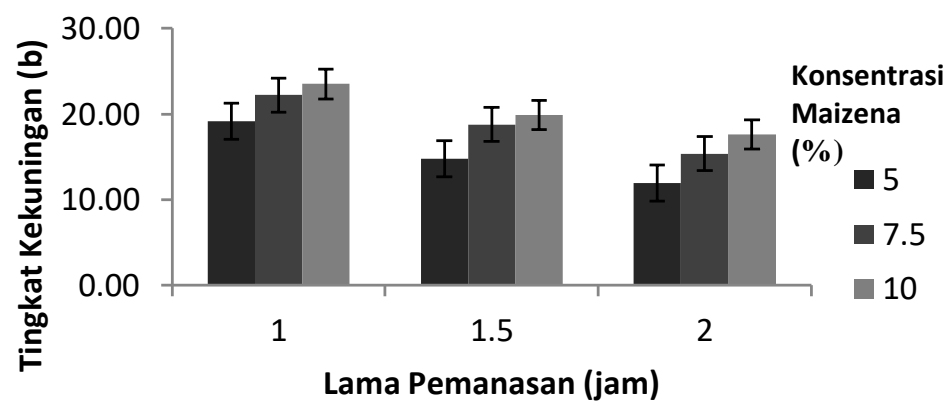

Gambar 11. Pengaruh Lama Pemanasan (jam) dan Konsentrasi Maizena (\%) terhadap Tingkat Kekuningan Lempok Jambu Biji Merah

Semakin lama waktu pemanasan pada saat proses pembuatan lempok jambu biji merah maka tingkat kekuningan (b) akan semakin rendah, sedangkan semakin banyak konsentrasi maizena yang ditambahkan maka tingkat kekuningan (b) akan semakin tinggi. Tingkat kekuningan lempok jambu biji merah terendah diperoleh dari perlakuan lama pemanasan 2 jam dengan konsentrasi maizena $5 \%$ yaitu sebesar 11.93, sedangkan tingkat kekuningan tertinggi diperoleh dari perlakuan lama pemanasan 1 jam dengan konsentrasi maizena $10 \%$ yaitu sebesar 23.50 . 


\section{Organoleptik}

Pada pengujian organoleptik lempok jambu biji merah dilakukan dengan pengujian tingkat kesukaan metode hedonic scale scoring. Pengujian ini panelis dimintakan tanggapan pribadinya tentang kesukaan atau sebaliknya (ketidaksukaan) terhadap rasa, aroma, warna dan tekstur dari produk lempok jambu biji merah. Rerata hasil uji hedonik dari 9 perlakuan terhadap parameter warna, aroma, rasa dan tekstur pada lempok jambu biji merah dapat dilihat pada gambar 12.
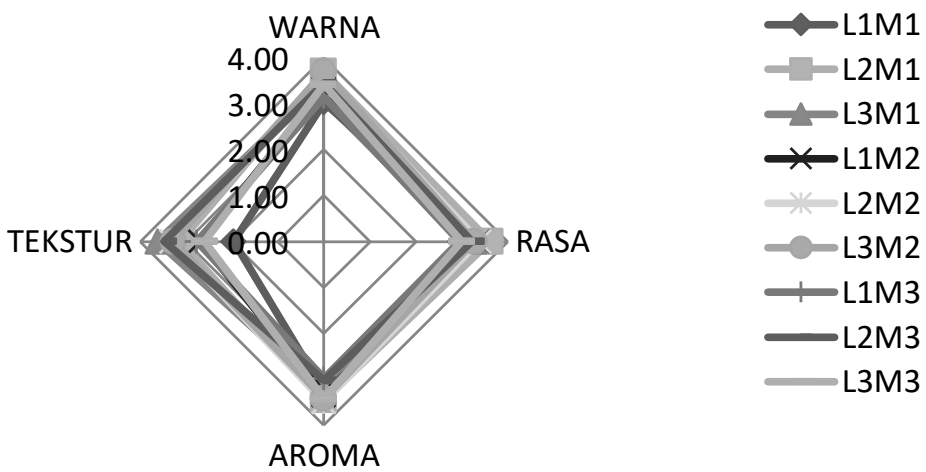

Gambar 12. Pengaruh Perlakuan Lama Pemanasan dan Konsentrasi Maizena Terhadap Tingkat Kesukaan Panelis Pada Setiap Parameter Lempok Jambu Biji

Grafik uji hedonik menunjukkan bahwa rata-rata dari empat parameter lempok jambu biji merah yaitu warna, aroma, rasa dan tekstur cederung menghasilkan mutu organoleptik yang naik kemudian turun. Hasil yang menjauhi titik pusat menandakan bahwa mutu organoleptik lempok jambu biji merah semakin disukai, sedangkan hasil yang mendekati titik pusat menandakan bahwa mutu organoleptik lempok jambu biji merah semakin tidak disukai.

\section{Perlakuan Terbaik}

Pemilihan perlakuan terbaik dilakukan untuk mengetahui perlakuan yang paling sesuai untuk mendapatkan lempok dengan parameter yang diinginkan. Pengujian perlakuan terbaik parameter kima, fisik, dan organoleptik lempok jambu biji merah Hasil pengujian perlakuan terbaik lempok jambu biji merah terhadap parameter fisik, kimia dan organoleptik dapat dilihat pada Tabel 2.

Tabel 2. Perlakuan Terbaik Kimia Fisik dan Organoleptik Lempok Jambu Biji Merah Akibat Perlakuan Lama Pemanasan dan Konsentrasi Maizena.

\begin{tabular}{ccc}
\hline Lama Pemanasan (jam) & Konsentrasi Maizena (\%) & $\begin{array}{c}\text { Nilai L Total } \\
\text { Terendah }\end{array}$ \\
\hline 1 & 5 & 0.5244 \\
& 7.50 & 0.4905 \\
1,5 & 10 & 0.5035 \\
& 5 & 0.4479 \\
2 & 7.50 & 0.4497 \\
& 10 & 0.4456 \\
& 5 & 0.3935 \\
& 7.50 & $0.3910^{*}$ \\
10 & 0.3994 \\
\hline
\end{tabular}

Keterangan: ( $\left.{ }^{*}\right)$ Perlakuan Terbaik

Tabel menunjukkan bahwa lempok jambu biji merah dengan pelakuan terbaik berdasarkan kimia, fisik dan organoleptik diperoleh dari perlakuan lama pemanasan 2 jam 
dengan konsentrasi maizena $7.50 \%$. Hal ini dikarenakan sebagian besar karakteristik fisik, kimia, dan organoleptik sesuai dengan karakter lempok yang diinginkan.

\section{SIMPULAN}

Perlakuan tingkat lama pemanasan berpengaruh sangat nyata terhadap kadar air, asam askorbat, total gula, serat kasar, tekstur, kecerahan, kekuningan, kemerahan, dan organoleptik. Perlakuan tingkat konsentrasi maizena berpengaruh sangat nyata terhadap kadar air, tekstur, kemerahan, kekuningan, dan organoleptik, sedangkan parameter total gula dan kecerahan berpengaruh nyata. Lempok jambu biji merah terbaik adalah lempok dengan perlakuan lama pemanasan 2 jam dan konsentrasi maizena $7.50 \%$.

\section{DAFTAR PUSTAKA}

AOAC. 1995. Official Methods of Analysis of the Association of Official Analytical Chemist. AOAC int. Washington D.C

Darwindra, Haris Rianto. 2009. Penoklatan Enzimatis. http://harisdianto.files.wordpress.com/2010/01/enzim-com.pdf. Diakses pada tanggal 25 Juli 2017

Desrosier, N.W. 1988. Teknologi Pengawetan Pangan. UI Press. Jakarta

Direktorat Gizi Depkes RI. 1996. Kandungan Gizi Jambu Biji. Departemen Kesehatan. Jakarta

Kementerian Pertanian. 2015. Statistik Produksi Holtikultura Tahun 2014. Direktorat Jendral Holtikultura Kementrian Pertanian. Jakarta

Parimin, S. 2005. Jambu Biji Budidaya dan Ragam Pemanfaatannya. Penebar Swadaya. Jakarta

Priscilla, I. 2013. Pengaruh Konsentrasi Bayam (Amaranthus blitum L.) dan Konsentrasi Agar terhadap Karakteristik Es Krim Nabati (Mellorine). Jurusan Teknologi Hasil Pertanian Fakultas Teknologi Pertanian. Universitas Brawijaya. Malang

Purnomo, H. 1995. Aktivitas Air dan Peranannya dalam Pengawetan Pangan. Universitas Indonesia Press. Jakarta

Rahayu, W.P. 2001. Penuntun Praktikum Penilaian Organoleptik. Jurusan Teknologi Pangan dan Gizi. Fakultas Teknologi Pangan. IPB. Bogor

Sudarmadji, S., Bambang, H dan Suhardi. 1996. Analisa Bahan Makanan dan Pertanian. Liberty Yogyakarta

Winarno, F.G. 1989. Enzim Pangan dan Gizi. PT. Gramedia Pustaka Utama. Jakarta

Zeleny, M. 1982. Multiple Criteria Decision Making, 2 ed. McGrawHill. New York 